\title{
Identitetsdannelse i midlertidige og spredte arbejdsfælleskaber - belyst via et relationelt perspektiv
}

\begin{abstract}
Artiklen argumenterer for, at udviklingen af medarbejdernes identitet og deltagelse i det danske arbejdsliv er en kompleks proces, hvor tre forskellige institutionaliserede ordningsmåder er opstået på forskellige tidspunkter i det 20. århundrede: kollektive forhandlinger, medbestemmelse og med-ledelse. Det antages, at disse institutioner er sat under pres som følge af fremvæksten af nye former for midlertidige og spredte arbejdsfælleskaber. Forfatterne ønsker at forstå, hvordan nye ordningsmåder bliver produceret i disse midlertidige og spredte arbejdsfælleskaber, og præsenterer teori, der kan bidrage hertil. ${ }^{1}$
\end{abstract}

\section{Indledning ${ }^{2}$}

I den første del af det 20. århundrede udviklede der sig i Danmark en kollektiv forhandlingsorden samtidig med, at arbejderne antog en identitet som lфnarbejdere og medlemmer af arbejderkollektiver (Lysgaard 1967) og af fagforeninger. Udviklingen blev regulativt institutionaliseret (Scott 1995, 35-37) ved Septemberforliget i 1899. Denne aftale stadfæstede arbejdernes formelle ret til at danne fagforeninger og arbejdsgivernes ret til at lede og fordele arbejdet - inden for en del af arbejdsmarkedet. I de følgende år indoptog og udviklede en stadig større del af deltagerne $i$ arbejdslivet (både det private og det offentlige) denne ordningsmåde ikke kun som en regulativ institution, men også som en kognitiv institution (Scott 1995, 35-45): den kollektive forhandlingsorden blev ikke kun institutio- naliseret af regler på arbejdsmarkedet (regulativt), men kom også til at angive den naturlige orden mellem parterne (kognitivt). Sidstnævnte medførte, at parterne fandt det normalt at se hinanden i rollerne som hhv. lønarbejdere og ledere. Det blev en del af deres identitet. Efter 2. verdenskrig har der været en tendens til at tillægge decentrale forhandlinger på den enkelte virksomhed stigende betydning - og til at inddrage flere emner $\mathrm{i}$ forhandlingerne. På trods af disse ændringer er ordningsmåden stadig baseret på en forestilling om, at arbejderne deltager i arbejdslivet som lønarbejdere i forhold til virksomhederne og som medlemmer i forhold til en fagforening. $\mathrm{Og}$ de fundamentale principper mht. arbejdsgivernes ret til at lede og fordele arbejdet har ikke ændret sig væsentligt (Due m.fl. 1994; Jørgensen m.fl. 1992; Knudsen 1995; 
Scheuer 1996; Westenholz 1994). I tråd med Friedland og Alford $(1991,248)$ kan vi sige, at den kollektive forhandlingsorden trækker på en institutionel logik (dvs. et sæt af materielle praksiser og symbolske konstruktioner, som konstituerer dens organiseringsmåde, og som organisationer og individer har mulighed for at videreudvikle), som kan betegnes som en kapitalismelogik: kapitalismens organiseringsmåde er akkumulation og kommercialisering af menneskelig aktivitet.

Siden 2. verdenskrig er der opstået en anden ordningsmåde - med-bestemmelse hvor medarbejderne blev/bliver konstitueret gennem medlemskab af to organisatoriske enheder. For det første fastholdes medarbejdernes medlemskab af fagforeninger (gennem 1950'erne var omkring 60\% organiseret; i dag er ca. $80 \%$ organiseret). For det andet bliver medarbejderne tildelt et nyt medlemskab af den virksomhed, hvor de er ansat. Medarbejderne blev/bliver garanteret retten til at diskutere forhold af fælles betydning med ledelsen gennem deres tillidsmænd, og virksomheden udviklede/udvikler tættere bånd til de ansatte. Dette dobbelte medlemskab kan også siges primært at trække på en institutionel kapitalismelogik, idet aftalen mellem fagforeningerne og arbejdsgivernes organisationer stadig er gældende. Dog er der nu inkorporeret et element af medarbejderdeltagelse i virksomhedens beslutningssystem, som er forankret $i$ en anden institutionel logik - den demokratiske. Ordningsmåden for et demokrati er deltagelse og fælles kontrol over menneskelige aktiviteter (Friedland \& Alford 1991, 248; Westenholz 1994).

Siden 1970'erne er der vokset en tredje ordningsmåde frem - med-ledelse - hvor alene virksomheden og ikke fagforeninger er blevet socialt konstrueret som stedet, hvor medarbejderne demonstrerer loyalitet, og hvor deres kollektive identitet bliver skabt. Inspireret af Selznick (1969), som udviklede begrebet 'den organisatoriske borger', har Christensen og Westenholz (1999 og 2000a) kaldt denne identitetsskabelse for borger $i$ virksomhedssamfundet. Et eksempel på denne udvikling er loven om medarbejdervalgte i danske aktieselskabers bestyrelse, som Christensen og Westenholz analyserer ved at trække på en insitutionel demokratilogik (Friedland \& Alford 1991, 248).

Kollektive forhandlinger, med-bestemmelse og med-ledelse er institutionaliserede ordningsmåder, der alle eksisterer i dag både som regulative og kognitive institutioner. Vi vil ikke her gå ind i, på hvilken måde eller hvordan ordningsmåderne er fordelt $i$ arbejdslivet, men blot nævne, at de alle tre sommetider er båret af enkeltindivider, og alle tre kan forekomme i den enkelte virksomhed (Westenholz 1999).

$\mathrm{Vi}$ antager imidlertid, at de tre ordningsmåder er sat under pres, og at vi i disse år ser en destabilisering, idet vi kan observere nye måder at organisere arbejdslivet på, hvor det ikke længere entydigt giver mening for deltagerne at trække på forestillingen om fagforeningernes eller virksomhedernes betydning eller deres egen rolle som lønarbejder eller borger i virksomheden. Medarbejderne deltager således i stigende grad i praktiske arbejdsrelationer, som bryder med de etablerede forestillinger om betydningen af fagforeningerne og virksomhederne, og dermed også betydningen af en lønarbejderidentitet og en virksomhedsidentitet. Set fra fagforeningernes og virksomhedernes side er en ny type medarbejdere under udvikling, der bliver defineret som deltagere i 'midlertidige og spredte' arbejdsrelationer i forhold til, hvad man er vant til (Barley 1996; Barley \& Kunda 1998; Engeström mfl. 1999; Garsten 1999; 
Nardi, Whittaker \& Schwartz 2000; Østerlund 1996). Nogle betegner disse medarbejdere som 'atypiske' (Garsten 1999, 606; Teknologisk Institut 2000).

Vi argumenterer ikke for, at sådanne arbejdsrelationer ikke er set før, eller at de er/bliver dominerende $\mathrm{i}$ arbejdslivet $\mathrm{i}$ de næste par år, men vi antager, at der kommer flere af dem, og at de muligvis peger på en trend $\mathrm{i}$ arbejdslivet, som vil komme til at spille en større rolle i fremtiden. Lad os nævne nogle konkrete eksempler.

Inden for en række virksomheder (bl.a. IT-virksomheder, konsulentfirmaer, bioteknologiske virksomheder, entrepen $\varnothing$ rvirksomheder) ser vi medarbejdere (f.eks. produktudviklere, sælgere, servicemedarbejdere), som er ansat i én virksomhed, og som i stigende grad arbejder sammen med ansatte $i$ andre virksomheder, med freelancere eller med forskere på universiteter. Sommetider er de geografisk placeret $i$ en anden virksomhed end den, de er ansat i. De krydser ikke kun virksomhedernes grænse fysisk, men antagelig også mentalt. Vi vil foreløbig betegne disse som virksomhedsgranseoverskridere.

I en lang række af forskellige virksomhedstyper er der også en stigende tendens til, at nogle medarbejdere får hjemmearbejdspladser, hvor de i en større eller mindre del af deres arbejdstid får et virtuelt forhold til arbejdspladsen.

Vi ser også en stigning af freelancere ikke kun inden for traditionelle brancher som journalistbranchen, men også inden for information- og kommunikationsteknologi, som vi synes er af særlig interesse. Det skyldes, at de har vist sig som en ny og hurtigt voksende gruppe, både som branche og som individer. For det første betyder det, at de ikke har noget historisk forbillede, som de forhandler identitet(er) i forhold til, hvilket er i kontrast til andre felter af sådant ar- bejde, f.eks. journalister eller mere traditionelt håndværk. For det andet spiller den implicerede teknologi en unik rolle: som det ligger i begrebet 'computer-nørd' så er individuelle sociale kompetencer koblet med computere på måder, som er forskellige fra andre arbejdsfelter; tempoet i den teknologiske udvikling gør, at uddannelse og kvalifikationer har kort levetid som gangbar mønt inden for feltet (tænk blot på Amanda-systemet til Arbejdsministeriet, som det tog fire år at udvikle, og som kostede flere hundrede millioner kroner, men allerede den dag, det blev taget i brug, blev kritiseret for 'forældet teknologi').

Som et sidste eksempel vil vi nævne det, vi kalder trækfugle på arbejdsmarkedet, dvs. mennesker, der arbejder på korttidskontrakter i virksomheder. Det kan være ingeniører eller andre teknikere, som bliver ansat til at løse konkrete problemer, hvorefter de bevæger sig videre til næste opgave og ansættelsesforhold i en anden virksomhed.

Vi antager, at medarbejdere, som krydser institutionaliserede grænser gennem deltagelse i midlertidige og spredte arbejdsfælleskaber, bliver sat i flertydige situationer mht., hvem de selv er, og hvem dem de arbejder sammen med er. Der er foretaget ganske få empiriske studier heraf og formålet med denne artikel er at lagge op til en diskussion af, hvordan vi teoretisk kan forstå, hvordan identiteter udvikles i arbejdslivet $i$ disse specielle arbejdsfalleskaber. Disse teoretiske reflektioner er et forspil til et egentligt empirisk studie, som vi kommer til at gennemføre i de kommende år.

\section{En relationel metateoretisk position}

Det forskningsspørgsmål, som vi har sat os for at begribe, starter med at spørge til, 
hvordan vi som forskere etablerer en repræsentation af mennesker, som deltager i midlertidige og spredte arbejdspraksiser. Disse mennesker bliver ofte betegnet som 'atypiske' eller 'udsatte'. Ordvalget peger på, at man (arbejdsmarkedsforskere, fagforeninger og sommetider også virksomheder og de involverede selv) mener, at disse mennesker bliver sat i en usikker og uklar situation mht. deres identitet. De bliver anskuet som værende 'uden stabil position eller tilknytning til en virksomhed eller fagforening' på deres vej gennem arbejdsmarkedet. Man antager, at uklarheden og usikkerheden opstår, fordi disse mennesker gennem deres arbejdspraksiser går på tværs af, eller ud af institutionaliserede ordningsmåder - i dette tilfælde af 'virksomheden' og/eller 'fagforeningen'. Vi vil imidlertid argumentere for, at man ligesåvel kan hævde, at de dominerende ordningsmåder i arbejdslivet er på vej til at blive deinstitutionaliserede, hvilket betyder, at det er disse institutioners identitet som bliver sat $i$ en uklar og usikker position. Vi er interesseret $i$ at forstå, hvordan orden bliver produceret (midlertidigt) i disse nye arbejdsfællesskaber, og hvordan den kan repræsenteres i identiteter og situationer, som gør det muligt for deltagerne at koordinere aktiviteter på måder, der (midlertidigt) giver mening til/for dem som kollektiver eller individer.

I dette afsnit positionerer vi os først metateoretisk i forhold til spørgsmålet om, hvordan identitet i det hele taget bør anskues, og beskriver derefter i næste afsnit, hvordan vi specifikt vil gå til det i vort projekt.

Vi funderer analysen i et relationel metateoretisk paradigme og vil indledningsvis beskrive en sådan position som en modsætning til et substantielt paradigme. En substantiel position tager, som Emirbayer (1997, 282/286) skriver, udgangspunkt $i$, at det er substanser af forskellig art (ting, væren, essens), som konstituerer den fundamentale enhed i al undersøgelse. Christensen og Westenholz (2000b) har inden for en sådan substantiel position identificeret to perspektiver: et social realistisk og et social konstruktivistisk. I et social realistisk perspektiv antages det, at aktører er 'virkelige': interesser og identiteter er medfødte og beslutningstagere har travlt med at afsløre og finde den virkelige (objektive) verden (f.eks. rationel aktørteori og spilteori, se bl.a. Abell, 1995). I et social konstruktivistisk perspektiv antages det, at aktører ikke opdager deres objektive (newtonske) verden og dens måde at operere på. De er socialt konstruerede og normfølgende aktører ('norm-following theory', se bl.a. March \& Olsen 1989). Inden for hvert af disse to teoretiske perspektiver skelner Christensen \& Westenholz (2000) mellem to analytiske niveauer: 'aktør niveau' og 'kollektivt niveau', en analytisk skelnen som minder om den, Emirbayer foretager mellem 'self-action' og 'inter-action'. På aktør/self-action niveauet antager man, at enheder handler ved hjælp af egen magt uafhængig af alle andre enheder. På det kollektive-/interactionsniveau (som ofte sammenblandes med et relationelt perspektiv) er enheder balanceret i forhold til andre enheder $\mathrm{i}$ årsagssammenhænge (Emirbayer 1997, 285):

"...where entities no longer generate their own action, but rather, the relevant action takes place among the entities themselves. Entities remain fixed and unchanging throughout the interaction, each independent of the existence of the other, much like billiard balls.«

Over for en sådan substantiel position - i dens mange varianter - er der nogle (inklu- 
sive forfatterne til denne artikel), der modsætningsvis formulerer en 'relationel position'. I en sådan position antages det, at personer alene træder i karakter i de relationer, som de indgår i. Personen kan ikke definere sig selv uden at trække på en social skabt forståelse af, hvilken situation personen står i og hvilken rolle personen spiller i relation til andre i 'spillet'. Personer er ikke billard kugler, men snarere krammebolde, som former sig/bliver formet i relationen. Samtidig former relationen ikke personerne på en determineret måde. I så fald ville vi have en slags normfølge situation, hvor der blandt deltagerne på forhånd var enighed om, hvilken situation de stod i og hvilken rolle, de skulle spille i situationen (a priori common logic of appropriateness). Vi forudsætter derimod, at der kan - og oftest vil være - uenighed og/eller uklarhed om, hvad det er for en 'situation/rolle, man er i', og at der sker en 'forhandling' mellem personerne om, hvilken situation/rolle man er i. Vi tilslutter os Emirbayer (1997, 289), når han skriver

»What is distinct about the transactional (relational) approach is that it sees relations between terms or units as preeminently dynamic in nature, as unfolding, ongoing processes rather than as static ties among inert substances«

og han fortsætter med at citere Dewey and Bentley $(1949,133)$

»...no one would be able successfully to speak of the hunter and the hunted as isolated with respect to hunting. Yet it is just as absurd to set up hunting as an event in isolation from the spatio-temporal connection of all the components."

Dette citat afspejler netop den pointe, vi vil have frem. Identiteter etableres, når subjektet bliver anerkendt $\mathrm{i}$ en relation til andre, men anerkendelse er noget, der 'forhandles' blandt subjekterne i en dynamisk udfoldende process.

Inden vi i næste afsnit beskriver tre nyere teorier, som vi vil trække på, vil vi - med risiko for at gentage os selv - tage to begreber op, som kan volde problemer, fordi de har forskellig mening inden for et substantielt og relationelt paradigme. Det drejer sig om identitetsbegrebet og forhandlingsbegrebet.

\section{Identitet}

I et substantielt paradigme forstås identitet som noget, der er knyttet til et isoleret individ. Individet har/er en identitet, og identiteten guider individets handlinger. Identiteten kan stamme fra psykologiske forhold eller være socialt konstrueret. Det væsentlige er, at identitetsbegrebet i både den psykologiske og den sociale version er en eksogen variabel i analysen, dvs. en variabel som forskerne kan tage for givet, når de forklarer, hvad der sker i f.eks. et arbejdsfælleskab.

I et relationelt paradigme vil vi ikke se isolerede identiteter. Identiteter vil altid være relationelle, eller som G.H. Mead skrev »Selves can only exist in relationship to other selves«. Wenger $(1998,151)$ udtrykker det på følgende måde:

»Identity in practice is defined socially not merely because it is reified in a social discourse as a lived experience of participation in specific communities. What narratives, categories, roles, and positions come to mean as an experience of participation is something that must be worked out in practice.(...)In the same way that meaning exists in its negotia- 
tion, identity exists - not as an object in and of itself - but in the constant work of negotiating the self."

Identiteter kan derfor ikke betragtes som eksogene variable, men vil være endogene i analysen: identitetsbegrebet kan ikke bruges til at forklare, hvad der sker, men derimod kan begrebet anvendes til at beskrive, hvad der er sket.

\section{Forhandling}

I et substantielt paradigme betragtes 'forhandlinger' som en form for interaktion mellem individer, som forfølger egne interesser/værdier ud fra en konsekvenslogik. Man forestiller sig, at individer handler ved at stille sig følgende spørgsmål: Hvad er mine alternativer? Hvad er mine interesser/værdier? Hvilke konsekvenser vil mine alternativer have for mine værdier? Hvorefter man vælger det alternativ, der har de bedste konsekvenser. (Denne rene individuelle rationelle model er blevet modificeret med antagelsen om individuel begrænset rationalitet, hvilket vi ikke nærmere vil komme ind på her). Individer handler imidlertid som oftest ikke i et socialt tomrum, men forhandler sig frem til et kompromis, der menes at indebære de bedste/mest acceptable konsekvenser set ud fra de involverede individers forskellige interesser/ værdier (se bl.a. March \& Simon 1958).

Inden for et relationelt paradigme sætter vi citationstegn rundt om 'forhandlinger', hvorved vi indikerer, at vi ikke bruger begrebet som ovenfor beskrevet. Vi forestiller os som alternativ, at der foregår en meningsskabelsesproces blandt deltagerne $\mathrm{i}$ arbejdsfælleskaberne, dvs. en social proces som er karakteriseret ved reduktion af flertydighed om, hvem deltagerne er (se bl.a. Weick 1993 og 1995). Hvordan sådanne flertydighedsreduktioner - 'forhandlinger' - foregår, er det et af formålene med vort kommende forskningsprojekt at folde ud (se også Wenger 1998).

Lidt forenklet kan man skelne mellem en forhandling $i$ et substantielt og relationelt paradigme ved at tale om, at i førstnævnte forhandler man om interessevaretagelsen, mens man i sidstnævnte 'forhandler' i meningsskabelsen.

\section{Udfoldelse af et relationelt paradigme ved hjælp af tre nyere teorier}

Vi vil i studiet trække på teoretisk beslægtede, nyere traditioner, der også har beskæftiget sig med lignende empiriske problemstillinger. Her vil vi fremhæve tre traditioner, der hver på sin måde bidrager til at belyse problemstillingen .

\section{Praksisfællesskaber (situeret læring)}

Denne tilgang begyndte for alvor med Jean Lave og Etienne Wengers (1991) bog Situated Learning. Her udvikler de et teoretisk perspektiv på læring, som går ud fra, at læring må forstås som deltagelse i praksisfallesskaber. Siden er blandt andet begrebet om praksisfællesskaber blevet kritiseret for at være upræcist eller ligefrem uklart. Jean Lave anvender nu kun denne term beskrivende (jf. Lave 1999), mens Etienne Wenger har arbejdet med at udvikle den til en mere anvendelig analytisk kategori (Wenger 1998a).

I vor læsning af Wenger bliver praksisfællesskab til et overbegreb for en række karakteristika ved de sociale sammenhænge, som mennesker tager del i, herunder deres arbejdsliv. Et praksisfællesskab er altså 
ikke det samme som f.eks. en arbejdsplads eller en organisation, men snarere en ny måde at se arbejdsliv på, der forsøger at bryde med forestillinger om bestemte faste strukturer, der er styrende eller danner rammerne for den daglige praksis.

Wenger benytter to begreber til at indfange forholdet mellem proces og struktur: deltagelse og reifikation (genstandsmæssiggørelse eller objektgørelse). Deltagelse er den hele tiden igangværende proces af handlen. Reifikation betegner det, at deltagere ind imellem betragter de igangværende processer som genstande og dermed mere stabile i tid og rum. På den ene side er der altså deltagelsesaspektet ved arbejdslivet, som er det, vi rent faktisk gør, de konkrete handlinger vi udfører, når vi arbejder. På den anden side er der reifikationsaspektet, som er det vi gør, når vi betragter vor (fælles) deltagelse som objekter. Reifikationen kommer f.eks. til udtryk ved at arbejdet bliver betragtet som et bestemt job, der kan beskrives i en funktionsbeskrivelse eller en jobprofil.

Pointen er, at begge aspekter spiller sammen på en måde, Wenger betegner 'dualitet'. På den ene side er arbejdslivet en lang række konkrete, situerede handlinger, og på den anden side er der elementer af stabilitet i det, som gør det muligt for os, at betragte det som en bestemt ting, som klart kan identificeres. En særlig form for reifikation foregår, når processerne bliver gjort til redskaber, der både kan være materielle og immaterielle, hvad vi her vil kalde teknologi.

Et eksempel på samspillet mellem deltagelse og de forskellige aspekter af reifikation er vor (dvs. forfatterne til denne artikel) brug af et tekstbehandlingsprogram til at skrive artiklen. På den ene side er der deltagelsesaspektet, som kan beskrives som en strøm af handlinger, der som sit mest umiddelbare resultat har den færdige arti- kel. Handlingerne er bl.a. samtaler mellem forfatterne, skrivning og læsning af udkast, afsendelse af manuskript til redaktør, læsning af referee- og redaktørkommentarer osv. Men der er også kaffedrikning, telefonsamtaler, e-mailbesvarelser, frokostpauser, uden hvilke artiklen ikke ville have fået netop den endelige form, der præsenteres for læseren. Vi deltager altså ikke blot i en aktivitet, der kunne kaldes 'artikelskrivning', hvilket ville være én slags reifikation, men også i en større sammenhæng, der kunne kaldes 'forskning og forskningsformidling'. Forskning er naturligvis også en reifikation, der i denne sammenhæng er interessant, fordi den tydeligvis går på tværs af institutionelle og organisatoriske grænser. Vi deltager ikke blot i forsknings-praksisfællesskabet på Handelshøjskolen, men også i en lang række andre private og offentlige fællesskaber, når vi skriver.

Disse sammenflydende deltagelser gør os blandt andet til 'forfattere', 'arbejdsmarkedsforskere', 'debattører' og 'kolleger'. Sådanne eksempler på reificerede identiteter er et mere middelbart resultat af artikelskrivningen, men de må ikke betragtes som færdigformede. Hvordan vi kan siges at være 'arbejdsmarkedsforskere' $i$ artiklen, er til forhandling og afhænger f.eks. af læsernes opfattelser og handlinger - hvilke reaktioner får vi, og hvilke inspirationer giver vi? Man kunne f.eks. forestille sig den situation, at en eller flere referees vil hævde, at artiklen ikke handler om arbejdsmarkedsforskning. Det vil betyde, at vor identitet som arbejdsmarkedsforskere blev sat til debat, og vi måtte argumentere tydeligere for, at de fortolkninger, vi benytter, er del af det falles projekt arbejdsmarkedsforskning udgør. Måske ville det være nødvendigt at benytte nogle flere af de begreber, der er anerkendt som centrale i feltet, eller modificere tekstens stilart til at være mindre aty- 
pisk, dvs. i højere grad benytte det falles repertoire blandt anerkendte arbejdsmarkedsforskere. På den anden side kunne vi også skærpe tonen og argumentere for, at vi forsøger at udvide repertoiret ved at bidrage med nye opmærksomheder, der i det gensidige engagement mellem arbejdsmarkedsforskere vil øge den sociale kompleksitet, dvs. udvide forståelsen af, hvad arbejdsmarkedsforskning er.

De tre fremhævede termer, 'fælles projekt', 'fælles repertoire' og 'gensidigt engagement' er dimensioner eller analytiske kategorier i Wengers måde at forstå et fællesskab på. Dermed kan identitetsbegrebet ikke sammenlignes med de traditionelle rolle- og positionsbegreber i sociologien, der forudsætter definerede funktionelle sammenhænge eller strukturer. Tilsvarende er identitet ikke et individuelt fænomen, der beskæftiger sig med den personlige integration. Man kan i denne tænkning ikke integreres med sig selv, men kun med andre i et praktisk fællesskab.

Men dermed er det ikke gjort - vi bruger jo også en del teknologi. Eksemplet er tekstbehandling, der som Wenger gør opmærksom på »reifies a view of the activity of writing « (Wenger 1998a, 59). Dvs. tekstbehandlingen er ét særligt redskab, som det er nødvendigt at være kyndig bruger af for at kunne begå sig i fællesskabet.

Hermed er vi nået et stykke af vejen $\mathrm{i}$ konkretiseringen af hvilke empiriske opmærksomheder, der er relevante for en undersøgelse af identitet $\mathrm{i}$ arbejdsliv ud fra en relationel position. Men der er behov for at gå videre end Wenger, der placerer identitetsforhandlingerne i praksisfællesskaber. Problemet for vort projekt er, at de deltagere, vi ønsker at undersøge, netop er kendetegnet ved løse koblinger. Vi kunne så blot hævde, at denne type deltagere vil støde på problemer med deres identitet (og praksis), men på den ene side er det utilfredsstillende at karakterisere fænomener som problematiske, blot fordi praksis ikke stemmer overens med en teoretisk model. Og på den anden side kan vi jo konstatere, at fænomenet eksisterer og endda tilsyneladende er i vækst, hvilket vi vælger at tolke som et behov for en videreudvikling af den teoretiske begribelse. Det vil vi i første omgang gøre ved at inddrage teorien om knotworking.

\section{Knotworking}

Knotworking er et begreb udviklet inden for den særlige teori om menneskelig virksomhed, der kaldes for 'activity theory', som er en videreførelse af den kulturhistoriske skole i russisk psykologi (Engeström 1987). Yrjö Engeström med flere (Engeström et al. 1999) bruger knotworking til at betegne en type praksis ('virksomhed'), som ikke er organiseret omkring et centrum. 'Knudearbejdet' skal forstås som en metafor for en pulsering af aktivitet, hvor deltagere kommer og går, uden på forhånd at have bestemte velafgrænsede roller, og hvor aktiviteten ligeledes ikke på forhånd har noget fast velafgrænset mål, nogen klar genstand. En slags løst koblet ad hoc organisering.

Dermed beskæftiger knotworking analyser sig tydeligvis med en lignende type af empiriske fænomener, som vi har i fokus. $\mathrm{Vi}$ forestiller os ${ }^{3}$ f.eks. en virksomhed, der $\emptyset$ nsker at indføre nye redskaber til at håndtere planlægning og udvikling af personaleressourcer. Ledelsen beslutter, at det skal være en delvist IT-baseret løsning og tager kontakt til en konsulentvirksomhed for at indgå en rammeaftale om udvikling og implementering af en softwareløsning, der skal individuelt tilpasses virksomhedens afdelinger. Herefter bliver der nedsat en projektorganisation med en kernegruppe be- 
stående af repræsentanter for virksomheden og konsulenterne, som løbende inddrager repræsentanter for de enkelte afdelinger $\mathrm{i}$ virksomheden, efterhånden som softwareløsningen skal implementeres.

I en analyse inspireret af knotworking, vil vi få øje på nye aspekter af identitetsforhandlingerne, der kommer til udtryk i de ad hoc organiserede arbejdsgrupper, som arbejder med udvikling, implementering og tilpasning. I (en lidt forenklet udgave af) Wengers termer går deltagerne ind i denne praksis som repræsentanter for deres respektive praksisfællesskaber, men efterhånden som arbejdet skrider frem, sker der en række bevægelser. Engeström m.fl. betegner det 'co-konfiguration', dvs. en gensidig udformning af relationer mellem deltagere, genstanden for praksis og den større sammenhæng, de indgår i. Relationerne er i denne analysemodel medieret ad tre veje:

1. via de redskaber, der indgår, hvilket i eksemplet blandt andet vil være det udviklingsværktøj, konsulenterne benytter til at programmere applikationen med.

2. via de regler, der indgår, f.eks. det opdrag, ledelsen har givet.

3. via den arbejdsdeling, der er, f.eks. den indbyrdes mere eller mindre eksplicitte aftale om ansvarsområder, der er indgået i gruppen.

Undervejs med arbejdet opstår der forstyrrelser i relationssystemet, som forandrer målet for praksis og deltagerne. Det fordrer en længere analyse end vi ønsker at give her, men kan illustreres ved, at en af repræsentanterne for en afdeling undervejs finder ud af, at hun ikke ønsker at arbejde i en mellemlederfunktion længere. Dette bliver klart for hende, blandt andet fordi arbejdet i projektgruppen med at udvikle et system til at registrere afdelingens medarbej- derressourcer bidrager med nye perspektiver på dels hendes egne kompetencer og dels karakteren af det daglige arbejde som mellemleder i afdelingen. Arbejdet i projektgruppen modificerer hvilke værdier, hun $\emptyset$ nsker i sit arbejdsliv.

Mere overordnet sker der også en lang række andre forandringer. Konsulenterne må revidere deres måder at arbejde på og overskrider derved den aftalte arbejdsdeling. Virksomhedens projektledere må i praksis modificere ledelsens opdrag, fordi de oplever dele af det som irrelevant i forhold til langt væsentligere problemer, der viser sig undervejs.

En af de ofte upåagtede faktorer er udviklingsværktøjet, der bliver brugt til programmering af applikationen. Nogle af de funktioner, der bliver udtrykt ønske om at indføje i programmet, viser sig ikke at kunne programmeres. Der er tale om et sammenstød mellem 'praksislogikker' og 'programmeringslogikker'. I den daglige praksis er det f.eks. udbredt at opsøge den person $i$ afdelingen, der sidder inde med information om et område og blot spørge vedkommende. I programmeringen viser det sig imidlertid, at selv om systemet opsamler information om et område, personaleressourcer, er det ikke alle spørgsmål om dette område, som systemet kan bringes til at svare på. Databasen skal struktureres, før den kan opsamle information, men den valgte struktur sætter grænser for hvilke forespørgsler, der kan foretages. Efterhånden får denne indsigt som konsekvens, at projektet bliver radikalt omdefineret. Fra at være et system, der skal kortlægge personaleressourcer, som centrale beslutningstagere kan anvende til planlægning af organisationsudvikling, bliver det til et system, der skal bidrage til struktureringen af decentraliseret dialog mellem ledelse og medarbejdere. Dermed bliver ledelsens vision om et 
teknisk-rationelt fix på problemer erstattet af en vision om nye former for dialog om problemer.

Knotworking-perspektivet fremhæver at for at forstå, hvordan denne praksis udvikler sig og tager form, er det ikke tilstrækkeligt at søge efter specifikke grundlæggende præmisser, som praksis hviler på eller udspringer af. I stedet må man forsøge at se på de relationer, der bliver etableret, og hvordan disse relationerne hele tiden er med til at udforme, hvad de er relationer mellem.

Atter ser vi dog grunde til at gå videre for at finde passende teoretiske begreber til at lede og indfange vor empiriske opmærksomhed. I knotworking er der nemlig allerede forudsat en vis fastlæggelse af, hvilke typer af relationer, der skal fokuseres på (jf. de ovenfor oplistede tre punkter). Det kan have den betydning, at væsentlige forhold udelukkes eller kun vanskeligt inddrages. For at løse op for det problem i analysen inddrager vi den tredje teoretiske tradition, som er aktant-netværk teorien.

\section{Aktant-netværk}

Aktant-netværksteori (ANT) udspringer af videnskabs- og teknologistudier og kan bedst kort beskrives som en række metodiske principper, der forsøger at imødekomme det generaliserede symmetriprincip (Callon 1986, Latour 1993, Law 1994). I den oprindelige formulering af symmetriprincippet (jf. Bloor 1976) er pointen, at videnskabelige succeser og fiaskoer skal kunne forklares ved samme principper. Man må f.eks. ikke forklare et succesfuldt videnskabeligt eksperiment med, at det afspejler naturens orden og på den anden side et fejlslagent eksperiment med, at det skyldes sjusk hos laboratoriemedarbejderne. Det kaldes asymmetriske forklaringer, der implicit priviligerer skiftevis naturen og det sociale som de steder, hvor årsager skal findes. I ANT tages denne pointe ud i sin yderste konsekvens, og man hævder, at intet på forhånd kan priviligeres, men at alt må forklares ud fra de samme præmisser. F.eks. kan man ikke forklare et flystyrt med menneskelige fejl, hvis man samtidig hævder, at når fly ikke styrter ned, kan det forklares med effektiv teknologi. Begge tilfælde, at et fly styrter ned eller ej, skal forklares på 'samme måde', dvs. typisk som en blanding af f.eks. teknik og mennesker. Dette gøres i ANT ved at operere med en semiotisk inspireret, lidt fremmedartet terminologi, hvoraf vi her kun vil komme med få eksempler.

'Hybrider' er en betegnelse, der skal rumme det forhold, at væsener (entiteter) i en given sammenhæng bedst beskrives som sammensat af forskellige typer af materialer, hvilket også kaldes 'heterogenitet'. Når entiteter $\mathrm{i}$ en beskrivelse af, hvad der sker $\mathrm{i}$ en sammenhæng tilskrives handlekraft, kaldes de også 'aktanter', dvs. 'de, der gør noget'. Aktanter betragtes ofte bedst som hybrider, der opstår som en effekt i heterogene netværk. Dvs. når vi udpeger noget eller nogen som det, der handler i en given sammenhæng, må det samtidig være muligt at se dem som opstået i relationer mellem forskellige materialers dynamiske forbindelser. Dermed er subjektivitet, det at have status som handlende agent, noget der i ANT kan betragtes som konstitueret gennem konkrete relationer mellem forskellige materialer i en praksis. Dette står i modsætning til, at subjektivitet er noget, der på forhånd antages at tilhøre forud bestemte entiteter, typisk mennesker, hvilket er tilfældet i både praksisfællesskabs-tænkningen og knotworking tilgangen.

Det vi ser ANT som anvendeligt til i vor projekt er at skabe opmærksomhed om to forhold. På den ene side, hvordan subjekti- 
viteter bliver skabt i forbindelser mellem teknologier og forskellige andre materialer, og på den anden side, at identiteter er flersidige, dvs. aktører har ikke blot én identitet, men flere, der spiller sammen i et netværk af relationer.

Vi kan eksemplificere disse ANT-opmærksomheder ved kort at vende tilbage til de to førnævinte konkrete eksempler.

I vor forskningspraksis er det en pointe, at vi benytter en tekstbehandling og ud fra praksisfællesskab perspektivet må være kyndige brugere af den. Ved hjælp af ANT kan vi nu også få øje på, at tekstbehandlingen er en teknologi, som har både materielle og immaterielle bestanddele. Blandt de materielle bestanddele kan nævnes computerskærm, tastatur, mus, programkode, kontorstol og printer. Som en ergonom vil vide har dette væsentlig indflydelse på udformning af vort arbejdsliv: ryglidelser, museskader, skærmbriller og netværksnedbrud er eksempler på problemer, mens den nemmere kommunikation indbyrdes mellem forfatterne, til redaktionen og mellem redaktion og trykkeri er eksempler på lettelser. Blandt de immaterielle bestanddele er de programlogikker, som indgår i tekstbehandlingsprogrammel og styresystem, samt konventioner for sprogbrug og lay-out. Hele grænsefladen forudsætter eller konfigurerer en særlig bruger, der kan afkode ikoner, ræsonnere sig frem til placering af menupunkter, gennemskue uventede forespørgsler og tolerere ugennemsigtige ventetider. Vi bliver disciplineret til at skrive på bestemte måder, men disciplinerer også vor tekst. På denne måde bliver vor identitet også 'patient hos fysioterapeuten', 'IT-brugere', 'kunder', 'sprogkompetente'.

I knotworking eksemplet blev udviklingsværktøjets indflydelse på udformningen af genstanden for praksis fremhævet. Med ANT-perpektivet vil vi få øje på, at ud- viklingsværktøjets effekter også slår igennem på subjektiviteterne og identiterne hos deltagerne i projektet: Når en afdelingsrepræsentant $\emptyset$ nsker en særlig funktionalitet indbygget i applikationen, og konsulenterne derefter fors $\emptyset$ ger at efterkomme $ø$ nsket, viser de sig magtesløse. Udviklingsværktøjet er for stærkt til, at de kan tøjle det i deres tjeneste. Konsulenterne må derfor svare tilbage, at det ikke kan lade sig gøre, hvilket giver anledning til, at de øvrige deltagere eksplicit betvivler deres kompetence. For at genvinde respekten (og fastholde kontrakten), forsøger konsulenterne derfor at forklare, hvordan databasestruktur og applikationprogrammering hænger sammen og derved retfærdiggøre, at fejlen ikke ligger hos dem, men i udviklingsværktøjet, og at det i øvrigt ikke er en fejl, men et grundlæggende vilkår for programmering. I ANT-udlægningen bliver konsulenternes subjektivitet udfordret af relationerne mellem brugerønsker og programmeringslogikker. De får reduceret deres handleevne, hvilket vender tilbage i form af en identitet som inkompetente eksperter. Konsulenterne forsøger så at retablere subjektiviteten ved at mobilisere udviklingsværktøjet som en allieret $i$ forhandlinger med aftagerne om 'hvad der kan lade sig gøre', hvorved de på en gang bliver kompetente igen ved at kunne belære brugerne, men samtidig kan ses som talerør for et komplekst netværk af teknologier bestående af udviklingsværktøjet, computerakitektureren, og en tekniskrationel udgave af 'konsulentkompetencer'. Konsulenternes identitet som eksperter kan ses som et 'obligatorisk passagepunkt' for projektets videre forløb, eller i hvert fald deres fortsatte deltagelse. Hvis de ikke bliver accepteret som eksperter, men i stedet bliver opfattet som inkompetente, vil samarbejdsaftalen efter al sandsynlighed blive opsagt, og projektet må opgive at fortsætte 
på de hidtidige præmisser. Hvis de derimod bliver accepteret som eksperter, er der skabt et nyt udgangspunkt for forhandlinger om, hvordan problemerne skal håndteres $\mathrm{i}$ det videre forløb.

\section{Afslutning}

I artiklen argumenterer vi for, at nye former for midlertidige og spredte praksisformer inden for arbejdslivet er under udvikling. Det sker inden for mange områder, bl.a. ITog bioteknologi. Medarbejdere krydser i stigende grad virksomhedsgrænser ved at arbejde sammen over grænserne, ved at arbejde som freelancere eller som trækfugle på arbejdsmarkedet o.l. Disse medarbejdere omtales sommetider som 'atypiske' eller 'udsatte', fordi de anskues som uden en stabil position i forhold til gængse institutioner som fagforeningerne eller virksomhederne. Vi vil imidlertid snarere argumentere for, at de dominerende ordningsmåder i arbejdslivet bliver deinstitutionaliseret i disse år, hvilket betyder, at det for en del ikke er naturgivet, at man $\mathrm{i}$ arbejdslivet henter sin identitet som medlem af en fagforening med dertil hørende identitet som 'lønmodtager' - eller som ansat i en virksomhed med dertil hørende identitet som 'borger $\mathrm{i}$ virksomheden'. Identitet og tilhørsforhold er ikke noget man er/har, men er noget som man udvikler, når man bliver anerkendt i en relation til andre, hvor anerkendelsen er noget, som 'forhandles' blandt de involverede i de midlertidige og spredte arbejdspraksiser. Sådanne 'forhandlinger' er præget af, at der sker en midlertidig reduktion af flertydighed af, hvem de involverede 'er'.

Vi kan sammenfatte vor forståelsesform $i$ fire punkter. For det første foreslår vi, at identiteter skal ses som endogene variable $\mathrm{i}$ analysen og ikke som eksogene psykologiske eller kultursociologisk variable. Det be- tyder, at identiteter ikke kan tages for givne i en analyse, men må forstås som noget, der udvikler sig. For det andet ser vi ikke identitetsudvikling som noget, der er knyttet til et enkelt individ - psykologisk eller kultursociologisk - men som et relationelt fænomen, eller med G. H. Meads ord »selves can only exist in relationship to other selves«. For det tredje lægger vi op til, at identitet ikke nødvendigvis hører til i relationen mellem forudbestemte enheder (typisk individer), men derimod er noget, som skabes i forbindelser mellem teknologier og forskellige andre materialer. $\mathrm{Og}$ for det fjerde må identiteter forstås i flertal, idet en aktør kan have mere end én identitet, som spiller sammen i et netværk af relationer.

I de kommende tre år vil forfatterne ved hjælp af ovenstående forståelsesramme mere konkret forsøge at begribe identitetsdannelser $\mathrm{i}$ arbejdsliv, gennem et empirisk studie af medarbejderes deltagelse i midlertidige og spredte praksiser. Vi håber dermed at kunne bidrage til at afmystificere/normalisere en gruppe af medarbejdere, som i dag går under betegnelser som 'atypiske', 'udstødte', 'truede' o.l.

\section{Noter}

1. En forløber for denne version blev præsenteret på EGOS (European Group for Organizational Studies) $16^{\text {th }}$ COLLOQUIUM, session 2: Action, Learning and Collective Practice, $2^{\text {nd }}-4^{\text {th }}$ of July 2000 , Helsinki School of Economics, Finland. Vi vil gerne takke deltagerne for konstruktive kommentarer. Det samme gælder to kritiske referees og redaktøren, som har givet konstruktive forslag til ændringer af det første udkast.

2. I foråret 2000 startede vi et forskningsprojekt om den sociale konstruktion af identiteter, når mennesker deltager $\mathrm{i}$ midlertidige $\mathrm{og}$ spredte arbejdspraksiser. Projektet vil vare i 
3-4 år. Derfor er teksten i denne artikel ikke en fortolkning og bearbejdning af empiriske data, men en markering af, hvordan vi teoretisk vil belyse problemstillingen.

3. Eksemplet er taget fra konkrete erfaringer, men her modificeret af hensyn til den illustrative værdi.

\section{Litteratur}

Abell P. (1995): The New Institutionalism and Rational Choice Theory, i W.R. Scott \& S. Christensen (eds.): The Institutional Construction of Organizations. International and Longitudinal Studies, Thousand Oaks, Sage Publications.

Barley S.R. (1996): Technicians in the Workplace: Ethnographic Evidence for Bringing Work into Organization Studies, Administrative Science Quarterly, 41, 404-441.

Barley S.R. \& Kunda G. (1998): Bringing Work Back In. Paper presented at the SCANCOR Conference 'Future of Organizations', Stanford, USA.

Bloor D (1976): Knowledge and Social Image$r y$, London, Routledge \& Kegan P.

Callon M. (1986): Some Elements of a Sociology of Translation, i Callon, Law \& Rip (eds.): Mapping the Dynamics of Science and Technology, London, Macmillan.

Christensen S. \& Westenholz A. (1999): Medarbejdervalgte i danske virksomheder-fra lonarbejder til borger $i$ virksomhedssamfundet, København, Handelshøjskolen Forlag.

Christensen S. \& Westenholz A. (2000a): Den sociale konstruktion af kollektive aktorer. Institutionalisering af medarbejdervalgte i danske bestyrelser, Upubliceret papir, Institut for Organisation og Arbejdssociologi, Handelshøsjkolen i København.

Christensen S \& Westenholz A. (2000b): Collective Decision-Making - toward a relational perspective, American Behavioral Scientist, vol. 43, no. 8, 1301-1315.

Dewey J. \& Benley A. F. (1949): Knowing and the Known, Boston, Beacon Press.
Due J., Madsen J.S. \& Strøby Jensen C. (1994): The survival of the Danish Model. A historical sociological analysis of the Danish system of collective bargaining, København, Jurist- og Økonomforbundets Forlag.

Engeström Y. (1987): Learning by Expanding an activity-theoretical approach to developmental research, Helsinki, Orienta-Kosultit Oy.

Engeström Y., Engeström R. \& Vähäaho T. (1999): When the center doesn't hold, the importance of knotworking, i S. Chaiklin, M. Hedegaard \& U.J. Jensen: Activity Theory and Social Practice, Cultural-Historical Approaches, Aarhus University Press.

Emirbayer M. (1997): Manifesto for a Relational Sociology, American Journal of Sociology, vol. 103, no. 2:281-317.

Friedland R. \& Alford R.R. (1991): Bringing society back in: symbols, practices, and institutional contradictions, i W.W. Powell \& P.J. DiMaggio (Eds.): The new Institutionalism in Organizational Analysis, 232-263, Chicago, University of Chicago Press.

Garsten C. (1999): Betwixt and Between: temporary Employees as Liminal Subjects in Flexible Organizations, Organizational Studies, vol. 20. issue 4, 601-617.

Jørgensen H. et al. (1992): Medlemmer og meninger. APL-projektet, København, LO \& CARMA.

Knudsen H. (1995): Employee Participation in Europe, London, Sage Publications.

Lave J. (1999): Laring, mesterlare, social praksis, i K. Nielsen \& S. Kvale: Mesterlare, København, Hans Reitzel.

Lave J. \& Wenger E. (1991): Situated Learning, Legitimate Peripheral Participation, Cambridge University Press.

Latour B. (1993): We Have Never Been Modern, London, Harvester Wheatsheaf.

Law J. (1994): Organizing Modernity, London, Blackwell.

Lysgaard S. (1967): Arbeiderkollektivet, Oslo, Universitetsforlaget.

March J. \& Simon H.A. (1958): Organizations, New York, Wiley. 
March J. \& Olsen J.P. (1989): Rediscovering Institutions, The Organizational Basis of Politics, New York, The Free Press.

Nardi B.A., Whittaker S. \& Schwarz H. (2000): It's Not What You Know, It's Who You Know, Work $\mathrm{i}$ the Information Age, First Monday, vol. 5, no. 5. (http://firstmonday. org/issues/issue5_5/nardi/)

Scheuer S. (1996): Falles aftale eller egen kontrakt $i$ arbejdslivet, København, Nyt fra Samfundsvidenskaberne.

Scott W.R. (1995): Institutions and Organizations, Thousand Oaks, Sage.

Selznick P. (1969): Law, Societies, and Industrial Justice, New York, Russell Sage.

Teknologisk Institut, Erhvervsanalyser (2000): AC'ere $i$ atypiske beskaftigelsesrelationer Sammenfatning.

Weick K.E. (1993): Sensemaking in Organizations: Small Structures with Large Consequences, i J.K. Murnighan (ed.): Social Psychology in Organizations, Advances in Theory and Research, 10-37, Englewood Cliffs, NJ, Prentice Hall.
Weick K.E. (1995): Sensemaking in organization, Thousand Oaks, Sage.

Wenger E. (1998a): Communities of Practice Learning, Meaning, and Identity, Cambridge, University Press.

Wenger E. (1998b): Communities of Practice. Learning as a social system, Systems Thinker.

Westenholz A. (1994): Modeller af arbejdspladsdemokrati efter 2. Verdenskrig, Fra et logik- til et paradoksperspektiv med fokus på det organisatoriske niveau, Doktorafhandling, Handelshøjskolen, København.

Westenholz A. (1999): Medarbejderdeltagelse i ledelsen af arbejdslivet - en historisk analyse med fokus på danske forhold, pp. 23-38 i S. Christensen \& A. Westenholz 1999a: Medarbejdervalgte i danske virksomheder-fra lonarbejder til borger $i$ virksomhedssamfundet, København, Handelshøjskolens Forlag.

Østerlund C. (1999): Salgslærlinge på tværs, pp. 147-161 i K. Nielsen \& S. Kvale (red.): Mesterlare - laering som social praksis, København, Hans Reitzels Forlag.

David Metz er cand.psyk. og kandidatstipendiat ved Institut for Organisation og Arbejdssociologi, Handelshøjskolen i København.

Email: dtm.ioa@cbs.dk

Ann Westenholz er mag.scient.soc./dr. merc. og forskningsprofessor ved Institut for Organisation og Arbejdssociologi, Handelshøjskolen i København.

Email: aw.ioa@cbs.dk 